\section{ASSESSMENT OF CONFLICTS AT WORK PLACE AND SOCIAL SUPPORT AMONG MARKETING PROFESSIONALS}

KEY WORDS: Stress, Conflicts at work, Social support Marketing professionals
Varnam Radhika

\section{Velivelli Vijaya}

\section{Lakshmi}

Research Scholar, Department Of Resource Management And Consumer Sciences, College Of Community Science, Professor Jayashankar telangana State Agricultural University, Hyderabad

Professor And University Head, Department Of Resource Management And Consumer Sciences, College Of Community Science, Professor Jayashankar telangana State Agricultural University, Hyderabad

Now a day's most of the private company employees especially marketing related professionals are facing both mental and physical stress in their work place. The present study was conducted to know about the conflicts at workplace that lead to stress and social support at work to reduce the stress among marketing professionals. An exploratory research design was followed. Sample size of 30 respondents from marketing background was selected by using purposive sampling technique. For both the conflicts at workplace and social support, standard scales were adopted to collect the data. Correlation was used to compare the data. Results exposed that most of the respondents have very much social support from their spouse, friends and relatives. Respondents have moderately agreed for having conflicts at work place which led to stress. Significant positive relationships were found between income and social support; while significant negative relationships were observed between income and conflicts at workplace.

\section{INTRODUCTION}

Merriam Webster (1998) defined stress as a physical, chemical or emotional factor that causes bodily or mental tension and may be a factor in disease causation. It is a normal reaction when the brain recognizes a threat.When the threat is perceived, the human body releases hormones that activate its "fight or flight" response.

Marketing is a dynamic field and professionals engaged in marketing face many trials in their job surroundings, considered by intensified struggle, lack of time, lack of space, nonstop technical advancements, dynamic demands from organizational patrons and benefiters (Hall \& Savery, 1986).

Work-life conflict is defined as "a form of inter-role conflict in which work and family demands are mutually incompatible, meeting demands of both the domains is difficult" (Higgins, Duxbury \& Lyons, 2007). Thus any paid job creates stress as colleagues are from different backgrounds with different perspectives about the job and life. The present study was proposed to probe in to this aspect by framing following objectives:

\section{OBJECTIVES OF THE STUDY}

1.To identify the conflicts at work that leads to stress

2. To know the social support that helps in reducing stress in marketing professionals

\section{MATERIALS AND METHODS}

An exploratory research design was followed. The total sample contains 30 marketing professionals from 4 different pesticide companies in Telangana state. Purposive sampling technique was selected as the study was designed especially for marketing professionals.

Income, Family type and educational qualification were taken as independent variables while conflicts at work and social support were dependent variables.

Questionnaire was used to collect data related to conflicts at work having 15 items with 5 point scale having strongly disagree, moderately disagree, neither agree nor disagree, moderately agree and strongly agree. Social support scale was used which has 13 items with 5 point scale having very much, somewhat, a little, not at all and don't have any such person. These two scales were adopted from NIOSH generic job stress questionnaire and it was sent through Google form to collect data. Frequency and percentages descriptive statistics were used to analyze the Socio-demographic profile of the sample while Pearson's correlation coefficient was used for comparison of data.

\section{Hypothesis}

H01: There will be no significant relationship between educational qualification and social support

H02: There will be no significant relationship between income of the respondents and social support

H03: There will be no significant relationship between type of the family and conflicts at work

\section{MAJOR FINDINGS}

Results were presented under the following headings.

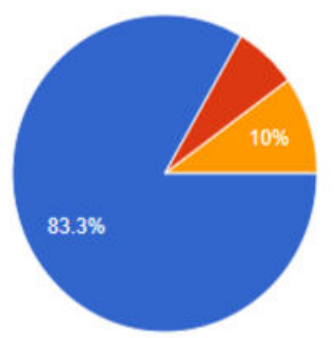

a. $21-30$

b. $31-40$

c. $41-50$

d. 51 and above

\section{Figure 1: Distribution of the respondents by age}

Regarding the age of the sample,data revealed that 83.3 per cent of the respondents were under the age group of 21-30 years and only 10 per cent were under the age group of 41-50 years Most of the respondents were young people (Fig 1).

Table 1: Educational Qualification of the respondents

\begin{tabular}{|c|c|c|}
\hline $\begin{array}{c}\text { Educational qualification } \\
\text { education }\end{array}$ & 1 & 3.35 \\
\hline $\begin{array}{c}\text { Lower secondary level of } \\
\text { education }\end{array}$ & 1 & 3.35 \\
\hline $\begin{array}{c}\text { Upper secondary level of } \\
\text { educy (N) }\end{array}$ & 9 & 30.00 \\
\hline Bachelors or equivalent & 19 & 63.33 \\
\hline Masters or equivalent & 19 & Percentage \\
\hline
\end{tabular}

It was observed from Table 1 that 63.3 per cent of the respondents' educational qualification was masters or equivalent and 30 per cent were with bachelors or equivalent degree and 6.7 per cent were with lower and upper secondary level of education. 
Table 2: Family type of the respondents

\begin{tabular}{|c|c|c|}
\hline Type of the family & Frequency (N) & Percentage (\%) \\
\hline Single member & 3 & 10.00 \\
\hline $\begin{array}{c}\text { Broken nuclear (2-3 } \\
\text { members) } \\
\text { (Headed without spouse } \\
\text { but with or without } \\
\text { unmarried children) }\end{array}$ & 3 & 10.00 \\
\hline $\begin{array}{c}\text { Nuclear family (3-4 } \\
\text { members) } \\
\text { (Headed spouse but with } \\
\text { or without unmarried } \\
\text { children) }\end{array}$ & 16 & 53.33 \\
\hline $\begin{array}{c}\text { Joint family (more than 4 } \\
\text { members) } \\
\text { (Lives grandparents and } \\
\text { parents together) }\end{array}$ & 8 & 26.77 \\
\hline
\end{tabular}

The Table 2reveals thatmore than half (53.33 per cent) of the respondents were from nuclear families followed by 27 per cent belonged to joint families while an equal proportion (10\%) belonging to either broken nuclear or single member families.
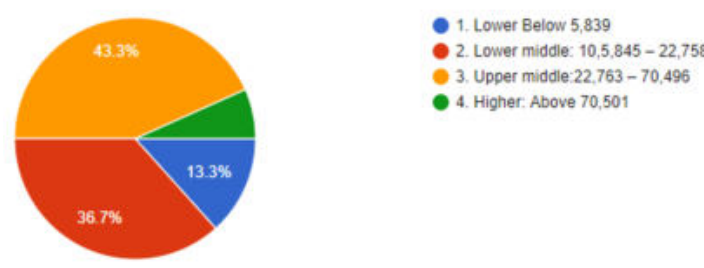

\section{Figure 2: Distribution of respondents by monthly income}

From the figure 2 , it was found that, regarding monthly income of the respondents, most of the respondents were falling under upper middle class income group i.e. 43.3 per cent followed by lower middle class income ( 36.7 per cent), lower below (13.3 per cent) and high income ( 6.7 per cent).

Regarding conflicts at work among respondents, a standard scale was used that consists of 15 statements. Respondents were asked to answer on a 5 point range i.e. strongly disagree, moderately disagree, neither agree nor disagree, moderately agree and strongly agree.

Few of the respondents had strongly disagreed with statements like disputes between their group and other group (23 per cent) and least of the respondents i.e. 3 per cent said friendliness among the members of their group and united feeling among members of their group.

Most of the respondents moderately agreed with the statements like coordination between the group members ( $47 \%)$, cooperation between their group and other group (43 $\%$ ) and least of the respondents said lack of mutual assistance between their group and other group (13\%).

Most of the respondents were neither agreed nor disagreed for the statements like other groups create problems for their group ( 40 per cent) while 3 per cent of the respondents were neutral about the existence of coordination among their group.

$$
\text { Conficss at nork amoeng markering professioests }
$$

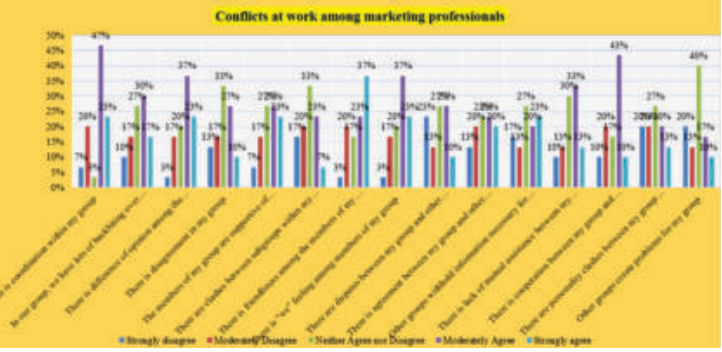

Figure 3: Distribution of respondents by conflicts at work Some of the respondents moderately disagreed with coordination within the group $\quad(20 \%)$, agreement between their group and other group (20\%) and least of them said lack of mutual assistance among the group members (10\%).

Most of the respondents strongly agreed with the statements like friendliness among the members of group (37 per cent) and less number of the respondent $(7 \%)$ said clashes between sub groups and within their group.

Table 3: Conflicts at work in marketing professionals

\begin{tabular}{|c|c|c|c|c|c|c|c|c|}
\hline Statements & \begin{tabular}{|l|} 
Strongly \\
disagree
\end{tabular} & \begin{tabular}{|l|} 
Moderatel \\
y Disagree
\end{tabular} & $\begin{array}{c}\text { Neither Agree } \\
\text { nor Disagree }\end{array}$ & $\begin{array}{c}\text { Moderately } \\
\text { Agree }\end{array}$ & $\begin{array}{c}\text { Strongly } \\
\text { agree }\end{array}$ & Total & $\begin{array}{l}\text { Mean } \\
\text { scores }\end{array}$ & Rank \\
\hline Coordination within my group & 2 & 12 & 3 & 56 & 35 & 108 & 21.6 & 2 \\
\hline $\begin{array}{c}\text { In our group, we have lots of backbiting } \\
\text { over who should do what job }\end{array}$ & 3 & 10 & 24 & 36 & 25 & 98 & 19.6 & 5 \\
\hline $\begin{array}{l}\text { Difference of opinion among the } \\
\text { members of my group }\end{array}$ & 1 & 10 & 18 & 44 & 35 & 108 & 21.6 & 2 \\
\hline Disagreement in my group & 4 & 10 & 30 & 32 & 15 & 91 & 18.2 & 10 \\
\hline $\begin{array}{l}\text { The members of my group are } \\
\text { supportive of each other's ideas }\end{array}$ & 2 & 10 & 24 & 32 & 35 & 103 & 20.6 & 4 \\
\hline Clashes between subgroups within my group & 5 & 12 & 30 & 28 & 10 & 85 & 17 & 12 \\
\hline \begin{tabular}{|c|} 
Friendliness among the members of my \\
group
\end{tabular} & 1 & 12 & 15 & 28 & 55 & 111 & 22.2 & 1 \\
\hline "We" feeling among members of my group & 1 & 10 & 18 & 44 & 35 & 108 & 21.6 & .2 \\
\hline Disputes between my group and other groups & 7 & 8 & 24 & 32 & 15 & 86 & 17.2 & 11 \\
\hline $\begin{array}{c}\text { Agreement between my group and other } \\
\text { groups }\end{array}$ & 4 & 12 & 21 & 28 & 30 & 95 & 19 & 9 \\
\hline $\begin{array}{c}\text { Other groups withhold information } \\
\text { necessary for the attainment of our } \\
\text { group tasks }\end{array}$ & 5 & 8 & 24 & 24 & 35 & 96 & 19.2 & 8 \\
\hline \begin{tabular}{|c|} 
Lack of mutual assistance between my \\
group and other groups \\
\end{tabular} & 3 & 8 & 27 & 40 & 20 & 98 & 19.6 & 5 \\
\hline $\begin{array}{c}\text { Cooperation between my group and } \\
\text { other groups }\end{array}$ & 3 & 12 & 15 & 52 & 15 & 97 & 19.4 & 7 \\
\hline \begin{tabular}{|c|} 
Personality clashes between my group \\
and other groups \\
\end{tabular} & 6 & 12 & 24 & 24 & 20 & 86 & 17.2 & 11 \\
\hline $\begin{array}{l}\text { Other groups create problems for my } \\
\text { group }\end{array}$ & 6 & 8 & 36 & 20 & 15 & 85 & 17 & 13 \\
\hline \multicolumn{8}{|c|}{ www.worldwidejournals.com } & 77 \\
\hline
\end{tabular}


From the Table 3, it was found that results related to mean scores obtained by the respondent's tackled conflicts at work. The scores obtained were 1-Strongly disagree, 2- Moderately disagree, 3- Neither agree nor disagree, 4-moderately agree and 5-Strongly agree.

Maximum mean score (22.1) was obtained for the statement that friendliness among the members of the group which was ranked $1^{\text {st }}$ and least mean score (17) was obtained for the statement that other groups created problems for their group which was ranked 13 .

\section{Table 4: Social support at work in marketing professional}

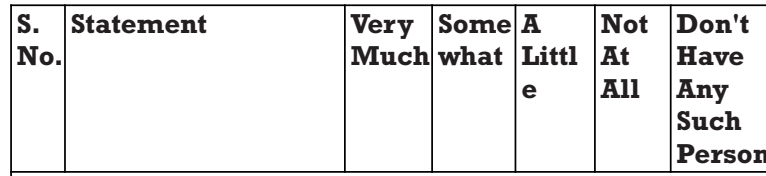

People make your work life easier by doing things

\begin{tabular}{|l|l|l|l|l|l|l}
\hline 1. & Your immediate & $30 \%$ & $27 \%$ & $30 \%$ & $13 \%$ & -
\end{tabular} supervisor (boss)

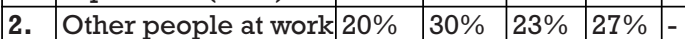
\begin{tabular}{|l|l|l|l|l|l|l|}
\hline 3. & $\begin{array}{l}\text { Your spouse, friends } \\
\text { and relatives }\end{array}$ & $33 \%$ & $20 \%$ & $23 \%$ & $17 \%$ & $7 \%$ \\
\hline
\end{tabular}

Table 4 showed that most of the respondents said that their spouse, friends and relatives (33\%) were very much supportive and made the work life easier when things get tough followed by immediate supervisor or boss (30\%) and other people at work $(20 \%)$.

Few of the respondents said other people at work (30\%) were somewhat supportive followed by immediate supervisor or boss (27\%) and their spouse, friends and relatives (20\%).

Some of the respondents said that their immediate supervisor or bosses $(30 \%)$ were a little bit supportive at work followed by other people at work and their spouse, friends and relatives $(23 \%)$.

Certain people said that other people at work (27 \%) were not at all supportive followed by their spouse, friends and relatives $(17 \%)$ and immediate supervisor or boss (13\%).

Only 7 per cent of the respondents don't have any persons like spouse, friends and relatives for social support at work.

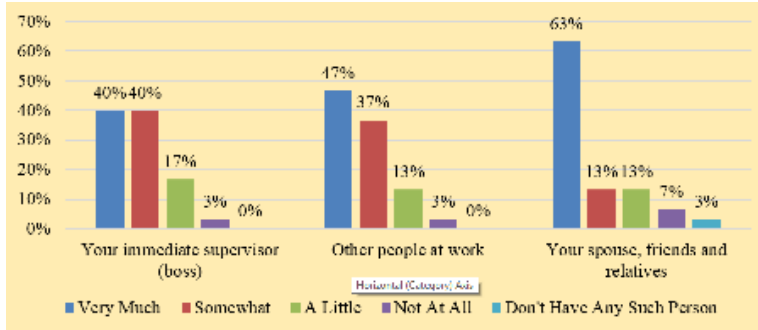

\section{Figure 4: Distribution of social support at work (ii)}

It was observed from the figure 4that most of the respondents said they felt Very much easy to talk with their spouse, friends and relatives $(63 \%)$ followed by other people (47 \%) and boss $(40 \%)$.

Few of the respondents said they felt Some what easy to talk with their boss (40\%) followed by other people at work (37\%) and their spouse, friends and relatives (13\%).

Some of the respondents said they felt a Little easy to talk with their boss $(17 \%)$, other people at work and their spouse, friends and relatives $(13 \%)$.

Few of the respondents said that it was not at all easy to talk with their spouse, friends and relatives $(7 \%)$, boss and other people at work (3\%).
Only 3 per cent of the respondents don't have any persons like spouse, friends and relatives for talking and sharing things.

Table 5: People be relied when things get tough at work(social support)

\begin{tabular}{|c|c|c|c|c|c|c|}
\hline $\begin{array}{c}\text { S. } \\
\text { No. }\end{array}$ & Statement & $\begin{array}{c}\text { Very } \\
\text { Much }\end{array}$ & $\begin{array}{c}\text { Some } \\
\text { what }\end{array}$ & $\begin{array}{c}\text { A } \\
\text { Little }\end{array}$ & $\begin{array}{c}\text { Not At } \\
\text { All }\end{array}$ & $\begin{array}{c}\text { Don't } \\
\text { Have } \\
\text { Any Such } \\
\text { Person }\end{array}$ \\
\hline 1. & $\begin{array}{c}\text { Your immediate } \\
\text { supervisor (boss) }\end{array}$ & $30 \%$ & $40 \%$ & $30 \%$ & - & - \\
\hline 2. & $\begin{array}{c}\text { Other people at } \\
\text { work }\end{array}$ & $27 \%$ & $47 \%$ & $20 \%$ & $3 \%$ & $3 \%$ \\
\hline 3. & $\begin{array}{c}\text { Your spouse, friends } \\
\text { and relatives }\end{array}$ & $30 \%$ & $33 \%$ & $17 \%$ & $20 \%$ & - \\
\hline
\end{tabular}

Table5 revealed that an equal percentage of the respondents said they were very much relied on boss $(30 \%)$ followed by spouse, friends and relatives while 27 per cent relied on other people when things get tough at work.

Few of the respondents said that they Somewhat relied on other people (47\%), boss (40\%) and spouse, friends and relatives $(33 \%)$ when things get tough at work.

Some of the respondents said that they relied little on boss (40 $\%)$, other people (20\%) and spouse, friends and relatives (17 $\%$ ) when things get tough at work.

An equal percentage of the respondents (3\%) said not at all and don't have any such person to be relied on when things get tough at work.

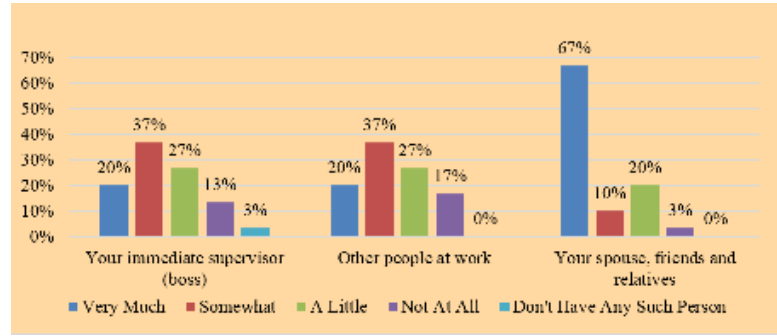

Figure 6: Distribution of respondents by social support at work (IV)

The figure 6 shows that most of the respondents said their spouse, friends and relatives (67 \%) were very much willing to listen to their personal problems followed by boss and other people $(20 \%)$ at work.

Few of the respondents said that their boss (37\%) and Other people at work (37\%) and spouse, friends and relatives (10 $\%$ ) were somewhat willing to listen their personal problems.

An equal percentage of the respondents said that their boss and other people (27 per cent); spouse, friends and relatives ( 20 per cent) were little bit willing to listen their personal problems.

Few of the respondents said that other people (17\%), boss $(13 \%)$ and their spouse, friends and relatives (3\%) were not at all willing to listen their personal problems. Only 3 per cent of the respondents don't have any such person like boss to listen their personal problems.

\section{STATISTICAL ANALYSIS}

Table 6: Correlation analyses between dependent and independent variables

\begin{tabular}{|l|c|c|c|c|}
\hline \multicolumn{2}{|c|}{ Dependent variable } & \multicolumn{3}{c|}{ Independent variable } \\
\cline { 3 - 5 } & Education & Income & Family type \\
\hline 1. & Social support & $.435^{*}$ & $.582^{* *}$ & NS \\
\hline 2. & Conflicts at work & NS & $-.468^{* *}$ & $-.404^{*}$ \\
\hline \multicolumn{3}{|c}{ www.worldwidejournals.com } \\
\hline
\end{tabular}


** = Significant at 0.01 level of probability

* = Significant at 0.05 level of probability

$\mathrm{NS}=$ Non significant

From Table 2 it could be observed that the coefficient of correlation between educational qualification and social support for marketing professionals was found to be $\mathbf{r}=$ $.435 *$ which was more than the table value of " $r$ " $(\mathbf{0 . 1 7 2})$ at 5 per cent level of significance. Hence the null hypothesis was rejected and alternate hypothesis was accepted. Therefore, it could be inferred that there was a positive and significant relationship between the educational qualification and social support for marketing professionals. It was clear from the value that as educational qualification increases, social support for marketing professionals increases.

The correlation between income of the respondents and social support in marketing professionals was found to be $\mathbf{r}=.582 * *$ which was more than the table value of " $r$ " (0.172) at 1 per cent level of significance. Hence the null hypothesis was rejected and alternate hypothesis was accepted. Therefore, it could be inferred that there was a positive and significant relationship between the income of the respondents and social support. Thus it was clear from the value that as income of the respondents increases, social support also increases which might be due to the increased social circle.

The correlation between income of the respondents and conflicts at work was found to be $\mathbf{r}=-.468 * *$ which was more than the table value of " $\mathbf{~ " ~}(\mathbf{0 . 1 7 2})$ at 1 per cent level of significance. Hence the null hypothesis was rejected and alternate hypothesis was accepted. Therefore, it could be inferred that there was a negative and significant relationship between the income of the respondents and conflicts at work in marketing professionals. It was clear from the value that as decrease in income of the respondents increases the conflicts at work which might be due to the professional jealousy, unfulfilled needs and desires etc.

The correlation between type of the family and conflicts at work was found to ber $=-.404 *$ which was more than the table value of " $r$ " (0.172) at 5 per cent level of significance. Hence the null hypothesis was rejected and alternate hypothesis was accepted. Therefore, it could be inferred that there was a negative and significant relationship between the type of the family and conflicts at work in marketing professionals. It was clear from the value that as type of the family changes, conflicts at work may increase or decrease.

Noor and Maad (2008) reported that family to work conflict, work life conflict and stress have a significant positive relationship with turnover intentions.

Mahmoodet al., (2017) revealed that no significant relation existed between emotional intelligence and occupational stress.

\section{CONCLUSION.}

Most of the respondents have social support and felt very much easy to talk with their spouse, friends and relatives followed by immediate boss and other people at work. And these people made the work life easier when things get tough in work place of the respondents. Few of the respondents were very much relied on boss than spouse, friends and relatives. Maximum of the respondents' spouse, friends and relatives were very much willing to listen their personal problems followed by boss and other people at work. Significant relationships were found between income and social support as income of the respondents' increases, their social support got increased while decrease in income of the respondents lead to increased conflicts at work. This implies that employees need to be trained to resolve conflicts on their own without undergoing any stress. Thus some training programmes need to be conducted on methods of resolving conflicts, developing interpersonal and intra personal relationships; and on stress coping strategies.

\section{REFERENCES}

1. Abdullah. N., Raza. S.A. and Akhtar.M.M. 2015. Measuring work stress of marketing professionals, Bussinessreview, 10(1): 118-193.

2. Hall, K., and Savery, L. K. 1986. Tight Rein, More Stress. Harvard Business Review,23(10): 1162-1164.

3. Higgins, D.C., Duxbury, D.L., \& Lyons, S. 2007. Reducing Work-Life Conflict: WhatWorks? What Doesn't? Executive Summary.

4. https://www.cdc.gov/niosh/topics/workorg/tools/pdfs/niosh-generic-jobstress-questionaire.pdf

5. Mahmood, Athar,Yadav, Kumar. L. 2017.Occupational Stress, Emotional Intelligence and Demography: $\mathbb{A}$ study among working professionals. International Journal of Business Insights \& Transformation. 10(7):72-79.

6. National Institute for Occupational Safety and Health (NIOSH).NIOSH Generic Job Stress Questionnaire, (513):533-8165.

7. Sarooj Noor and NaziaMaad 2008. Examining the Relationship between Work Life Conflict, Stress And Turnover Intentions among Marketing Executives in Pakistan.InternationalJournal of Business Management,3(11):93-102. 